\title{
Relationship between Learning Supervision and Work Motivation with the Performance of Madrasah Teacher Ibtidaiyah Sub-district of Padang Tualang
}

\author{
Mahli1 $1^{1}$, Muhammad Rivai ${ }^{2}$ \\ ${ }^{1}$ Master Student in Islamic Education Management, FITK, UIN-SU, Indonesia \\ 2 Lecturer in Islamic Education Management, FITK, UIN-SU, Indonesia \\ Email: mahli109@outlook.com
}

\begin{abstract}
One of the efforts given to assist teachers in improving their performance is learning supervision services and work motivation. In this case the role of the madrasa head is to carry out supervision of learning. Supervision of madrasa head learning is very meaningful because madrasa head is a person who immediately understands and sees the reality of the abilities possessed by the teacher. This study deals with relationship between learning supervision and work motivation with the performance of Madrasah teacher Ibtidaiyah Sub-district of Padang Tualang. This research is a quantitative study using the correlation research method. The results shows that providing supervision of madrasah head learning and work motivation together can improve teacher performance with a linearity line $\hat{Y}=95.92+0.363 X 1+0.515 X 2$.
\end{abstract}

Keywords: learning supervision; work motivation; teacher

\section{Introduction}

Teacher performance is the implementation of planning that have been prepared through good learning activity planning, namely by completing the learning device in the form of syllabus and learning implementation plan (RPP), otherwise bad learning activity planning if the teacher does not prepare the learning device in the form of syllabus and lesson plans. Implementation of performance is carried out by human resources who have the ability, competence, motivation, and interests. How madrasas value and treat their human resources will influence their attitudes and behavior in carrying out performance.

Preliminary data on teacher performance was obtained from interviews with the head of the MIN Bukit Tua madrasah on October 11, 2017 obtained information that at the beginning of the semester not all teachers in this madrasah collected a lesson plan (RPP), then explained by the head teacher of MIN Bukit Tua that not all teachers have made annual programs (prota) and semester programs (prosem). Furthermore, based on the results of interviews with teachers on October 11, 2017 obtained a picture that the learning tool in the form of lesson plans among most of the teachers taken from internet sources, based on sources from the internet the teacher changes it little by little according to the conditions of the madrasa.

One of the efforts given to assist teachers in improving their performance is learning supervision services. In this case the role of the madrasa head is to carry out supervision of learning. Supervision of madrasa head learning is very meaningful because madrasa head is a person who immediately understands and sees the reality of the abilities possessed by the teacher. Various research results show a positive relationship between learning motivation as variables that affect teacher performance, including: (1) research results by Zulkifli, Darmawan and Sutrisno (2014: 148) show work motivation and certification play an important role in efforts to enhance teacher welfare and performance in where the test results show the value $\chi^{2}=449,163$; $\mathrm{p}=0.542$, (2) the results of the Septiana, Ngadiman, Ivada, Elvia research (2013: 114) show there 
is a significant influence of work motivation on the performance of Wonosari Middle School teachers. Through the results of the calculations that have been done, the $t_{\text {count }}$ value of 3,294 is obtained with a significance level of 0.002 . While the table at a significant level of $5 \%$ is 1,993 . Because the value of $\mathrm{t}$ arithmetic $>\mathrm{t}$ table $(3,294>1,993)$ with $\mathrm{P}<0.05$, (3) the results of Guterres and Supartha's research (2016: 446) show that motivation has a positive and significant effect on Teacher Performance (Y). This is based on the value of the regression coefficient of motivation variable of 0.313 , with a significance level of $0.028<0.05$, (4) Ardiana's research results (2017: 14) shows that work motivation has a positive effect on the performance of accounting teachers with a contribution of $80.6 \%$, the rest $19.4 \%$ of the performance of accounting teachers is determined by other factors outside the study, (5) the results of Pujiyanti and Isroah's research (2015: 184) show that there is a positive and significant influence of Work Motivation on Teacher Performance as indicated by rx1y $=0.675, \mathrm{r} 2$ of $0.456, \mathrm{t}_{\text {count }}>\mathrm{t}_{\text {table }}$ namely: 7.085 $>1.671$, and (6) the results of Mishan's research (2014) show the work motivation of teachers and organizational culture together have a positive and significant effect on teacher performance $\left(\mathrm{F}_{\text {count }}=25,792\right)$. While partial testing shows that teacher work motivation and organizational culture have a positive and significant effect on teacher performance with $t_{\text {count }}$ of 3,150 and 3,437 , respectively.

\section{Review of Literature}

\subsection{The Nature of Teacher Performance}

Performance is the result of work that has a strong relationship with the strategic objectives of the organization, customer satisfaction and economic contribution (Armstrong and Baron in Wibowo, 2007: 2). Rivai et al (2005: 15) explain performance is the willingness of a person or group of people to do an activity and perfect it in accordance with their responsibilities with the results as expected.

Kirkpatrick and Nixon in Sagala (2007: 180) interpret performance as a measure of success in achieving the goals set (previously planned). Furthermore Harris, et al in Sagala (2007: 180) argued that performance is a behavior that shows competence relevant to realistic tasks and a description of behavior that is focused on the work context that is the behavior that is realized to clarify the job descriptions determine the performance that will fulfill desirable organizational needs. Performance is the result of interaction or functioning of the motivational elements $(\mathrm{m})$, ability (k), and perception (p) in a person (Mitchall in Bahri, 2011). Thus performance is the sum of one's abilities and work motivation. Means that someone with high ability and motivation tends to produce high performance. Conversely someone who has low ability and low motivation tends to produce low performance.

Based on the expert's explanation above, it can be understood that performance is a real achievement displayed by someone after carrying out their duties and roles in the organization. Performance is the desired result of behavior. But the behavior intended by Ivancevich, et al has a very broad scope, namely involving all individual activities in carrying out the tasks entrusted by the organization to him. There are various factors related to performance including motivation, incentives, communication intensity between leaders and subordinates, and others. According to Rivai et al (2005: 322) supervisors (supervisors) are very instrumental in improving their performance of working as guides, leaders, decision makers and encouraging their employees. In the context of madrasas the person who acts as a supervisor at the madrasa is the madrasa head.

In research teacher performance is the performance (performance) of a teacher to carry out his tasks related to learning. Indicators of teacher performance variables are performance in planning learning, implementing learning and carrying out assessment of learning outcomes. This 
performance is measured through a teacher performance appraisal tool (APKG) consisting of APKG I which is the performance in planning learning and APKG II which is the performance in implementing learning.

\subsection{The Nature of Madrasah Headmaster Learning Supervision}

Purwanto (2005: 76) providing supervision is a coaching activity that is planned to help teachers and other madrasa staff in carrying out their work effectively. Supervision according to Lazaruth (Kamars, 2005: 73) is an effort to encourage, coordinate and guide the growth of teachers so that they are better able to understand and more effectively appear in the learning process.

Supervision is an effort to stimulate, coordinate and continuously guide the growth of teachers in madrasas both individually and collectively, to be more effective in realizing all teaching functions. Meanwhile, Mc Nerney, who saw supervision as a procedure, gave direction and made a critical assessment of the learning process. Supervision is also interpreted by Burton and Brucker as a service technique whose main purpose is to study and improve together the factors that influence children's growth and development (Sah understanding, 2000: 17)

Sah understanding (2000: 19) explains supervision is an attempt to provide services to teachers both individually and in groups in an effort to improve teaching. This is in line with what was revealed by Purwanto (2005: 89) that teaching supervision is supervisory activities aimed at improving the conditions of both personnel and material that allow for the creation of better learning situations for the achievement of educational goals.

The supervision of madrasah head learning in this study is intended to be a service provided by madrasah principals to teachers in order to assist teachers in learning. Indicators of supervision of learning to madrasas are: (1) arousing and stimulating teachers in teaching, (2) procuring and equipping learning tools, (3) with teachers developing various appropriate teaching methods, (4) fostering cooperation among teachers, (5) enhance the quality and knowledge of teachers, and 6) foster cooperation with madrasa committees and other agencies.

\subsection{The Nature of Work Motivation}

Anoraga (2006: 35) explains work motivation is something that gives rise to enthusiasm or work motivation. The strengths and weaknesses of work motivation of a worker also determine the size of the achievement. Furthermore, Uno (2007: 71) defines work motivation as one of the factors that also determines a person's performance. Whether or not the influence of motivation on a person's performance depends on how much intensity the motivation is given. Manullang (2006: 166) explains work motivation is nothing but something that gives rise to motivation or enthusiasm for work. Work motivation is a morale booster.

Associated with teacher work motivation, Hariandja (2005: 321) suggests that teacher work motivation is the factors that direct and encourage one's behavior or desire to carry out an activity that is expressed in the form of hard or weak business. Furthermore, Uno (2007: 71) explains specifically about teacher work motivation is a process undertaken to move teachers so that their behavior can be directed to real efforts to achieve the goals set. Teacher's work motivation appears through responsibility in doing work, achievement achieved, selfdevelopment and independence in acting.

Furthermore, Uno (2007: 72) explained that work motivation of teachers is an encouragement from within and outside of a teacher to do something that is seen from two 
dimensions, namely: (1) the internal dimension with the indicators are: (a) the teacher's responsibility in implementing task, (b) carrying out tasks with clear targets, (c) has clear and challenging goals, (d) there is feedback on the results of his work, (e) has a feeling of pleasure at work, (f) always trying to outperform others, and (g) prioritized achievement of what he did, and (2) external dimensions with indicators: (1) always trying to meet the needs of life and work needs, (2) happy to get praise from what he did, (3) work with expectations of wanting to get incentives, and (4) working with hopes of getting attention from friends and superiors.

\section{Research Method}

This research is a quantitative study using the correlation research method, with the aim of describing three things, namely: (1) supervision of madrasah head learning, (2) work motivation, and (3) teacher performance. Furthermore, this study aimed to see: (1) the relationship between the supervision of school principals and teacher performance, (2) the relationship between work motivation and teacher performance, and (3) the relationship between the supervision of madrasah head learning and work motivation together with teacher performance.

The research population was all of the 51 Ibtidaiyah madrasah madrasah teachers in Padang Tualang sub-district, spread over 3 (three) Ibtidaiyah madrasas, where 2 public ibtidaiyah madrasas and one private madrasah madrasah madrasa. The entire population was sampled as a study. The research instrument for madrasah head supervision learning variables and work motivation is a questionnaire with a Likert scale model, while the teacher's performance is used APKG I and APKG II. The requirements test is conducted to test the normality, linearity, and independence between independent variables. Data analysis techniques used correlation and regression and simple correlation and regression and multiple correlations at the significance level $\alpha=0.05$.

\section{Discussion}

Research findings show: (1) there is a positive and significant relationship between the supervision of Madrasah Head learning and teacher performance, by making an effective contribution of $27.36 \%$. This means that variations that occur in the provision of supervision of Madrasah Head learning by $27.36 \%$ can be predicted in improving teacher performance, (2) there is a positive and significant relationship between work motivation and teacher performance by making an effective contribution of $44.40 \%$. This can be interpreted that the variations that occur in the variable work motivation by $44.40 \%$ can be predicted in improving teacher performance, and (3) there is a positive and significant relationship together between providing supervision of Madrasah Head learning and work motivation with teacher performance, by making an effective contribution of $41.30 \%$. This means that $41.30 \%$ of the variations that occur teacher performance can be predicted by the two independent variables.

The supervision of the madrasah head in this study is the teacher's response regarding the results of the supervision in the form of guidance in the task of the teacher as instructor conducted by the madrasa head in order to improve teacher professionalism. Supervision is carried out by the headmaster of madrasah regarding problem solving and not looking for problems together between the teacher and the headmaster. Madrasah principals who are willing to pay attention and help teachers in solving teaching problems, personal problems and professional problems will be able to give high performance teachers. The teacher will feel valued and cared for and so the teacher will be kind to the organization and the headmaster of the 


\section{Britain International of Linguistics, Arts and Education (BIoLAE) Journal \\ ISSN: 2685-4813 (Online), 2685-4805 (Print) \\ Vol. 1, No. 2, November 2019, Page: 60-68}

madrasa. The teacher has a positive perception of the implementation of learning supervision conducted by the Madrasah Head.

The findings of this study reinforce the results of Rahmanizar's (2007) research on the professionalism of MAN teachers in Tanjung Balai, finding that there is a positive relationship between teacher professionalism and Madrasah head leadership with teacher achievement motivation. Likewise, the research conducted by Salma (2007) about the performance of teachers in Bandar Lampung 9 Sub Rayon State Junior High School. The results showed that there was a relationship between instructional design knowledge, work motivation, and the leadership style of the Madrasah Head and Teacher Performance in the teachers of the Sub Rayon 9 Middle School in Bandar Lampung.

Samsuadi's research results (2015) found that the academic supervision of the supervisor and the leadership of the madrasah head jointly influenced the work discipline of the teachers of SMK Negeri 1 Bantaeng. Partially the supervisors' academic supervision did not affect the work discipline of SMK Negeri 1 Bantaeng teachers, while the leadership of the madrasa head influenced the work discipline of SMK Negeri 1 Bantaeng teachers.

The results of the research by Syukri, Harun, and Usman (2015) show that the implementation of academic supervision is carried out using a different academic supervision technique approach by each madrasa head, some are group and some are individual; and the efforts of madrasah principals in conducting academic supervision on improving teacher performance including conducting teacher meetings at madrasas, sending a number of teachers to attend upgrading, requiring all teachers to make lesson plans, and collecting all evaluation instruments subsequently spelled out in the final evaluation report.

Wahidah's research results (2015) showed that the teaching supervision program of SMK Negeri 1 Banda Aceh was oriented towards teacher guidance to improve teacher performance through compromise and discussion with teachers. In formulating goals it is not supported by supporting facilities and their implementation strategies. The implementation of this teaching supervision follows the stages, namely the initial planning, the implementation of observation, and the final stage, the learning process becomes effective, but not yet achieved by all teachers supervised according to the program. The techniques used by the madrasa head are individual techniques, group techniques and clinical supervision. 4) Follow-up actions include providing assistance and guidance to teachers who are still experiencing difficulties in carrying out their duties as a teacher, enhancing teacher professionalism through subject teacher meetings and training.

The results of Sudin's research (2008) showed that the general results of this study were the implementation of supervision in all subjects not running optimally, this was evident from the percentage obtained at $45.27 \%$. In the implementation of supervision that involves aspects of learning management is in the sufficient category that is $56.37 \%$. Implementation of supervision concerning aspects of increasing the academic ability of teachers in learning is in the sufficient category of $41 \%$. Implementation of supervision concerning aspects of professional development as subject teachers by supervisors was in the less category at $35.97 \%$.

Ismail's research results (2017) found that Madrasah Principals leadership had a direct influence on Teacher Teaching Performance of $11.4 \%$ and indirectly affected on Teacher Teaching Performance of $57.9 \%$. The indirect effect through teacher compensation was 34.3\% and through teacher work motivation was $23.6 \%$. While the rest is influenced by other variables. 
The second finding shows that as well as providing supervision of Madrasah Head learning, the work motivation of Madrasah Ibtidaiyah teachers in Padang Tualang sub-district also showed a positive and significant relationship with teacher performance with a correlation magnitude of 0.462 . This shows the category of the relationship between work motivation and the performance of madrasah ibtidaiyah teachers in Padang Tualang sub-district in the moderate category.

Work motivation is owned by the teacher, then the teacher will try to maximize the potential possessed to carry out the task seriously. Teachers who feel comfortable with their work are increasingly motivated at work. Therefore the task given by the headmaster to the teacher must be adjusted to the competency he has and will encourage him to carry out the work according to his ability. This is confirmed by Uno (2007: 71) defining work motivation is one of the factors that determine one's performance. Whether or not the influence of motivation on a person's performance depends on how much intensity the motivation is given. Manullang (2006: 166) explains work motivation is nothing but something that gives rise to motivation or enthusiasm for work. Work motivation is a morale booster.

Motivation is a form of reaction to human needs that gives rise to human existence that is the desire for something that has not been fulfilled in his life so that he is to take action to meet and satisfy his desires. With the level of appreciation given by madrasas to teachers in carrying out their duties adequately in accordance with the level of professionalism that is owned will guarantee the workforce of teachers as educators and instructors. The rewards received by the teacher do not have to be merely economic, but also in other forms such as speech, certificates or others. With good appreciation in the form of achievement, especially in carrying out their duties will be able to increase work motivation.

Teacher work motivation is motivation that causes a teacher to be enthusiastic in teaching because his needs have been met. The teacher works because of the needs that must be met such as to earn income, security, welfare, appreciation, recognition and socializing with the community. If these needs are met then the teacher will be encouraged to work. Fulfilling these needs is related to job satisfaction, where the teacher's expectations are met by the reality given by the organization. This is where the importance of the headmaster as a manager to be able to analyze in meeting teacher satisfaction, because teacher satisfaction is related to teacher work productivity.

The findings of this study reinforce the results of previous studies conducted by Lumbanraja, Absah, Concerned Lumbanraja (2014) showed that the work motivation of teachers has a positive and significant effect on the performance of the teacher concerned, where the $\mathrm{F}_{\text {count }}$ value of 23.448> from the $F_{\text {table }}(2.6)$. While the significance level is $0,000 .<0.05$. This condition contains the theoretical truth. In general, work motivation consists of intrinsic and extrinsic motivation. Intrinsic motivation is motivation that comes from within a person, without being influenced by external conditions.

Mishan research results (2014) show the work motivation of teachers and organizational culture together provide a positive and significant effect on teacher performance (Fcount $=$ $25,792)$. While partial testing shows that teacher work motivation and organizational culture have a positive and significant effect on teacher performance with tcounts of 3,150 and 3,437, respectively. 
The results of Yustiyawan and Nurhikmahyanti (2014) showed that the motivation of certified teachers had a significant effect on the performance of teachers in SMP Negeri 1 Surabaya with a value of $\mathrm{t}=9.839$ with significant $(0,000)<(0.05), 2)$ certified professional competence of teachers who had a significant effect on the performance of teachers in SMP Negeri 1 Surabaya with a value of $t=2.850$ with a significant $(0.007)<(0.05)$, 3) motivation and professional competence of teachers who have been certified simultaneously has a significant effect on the performance of teachers at SMP Negeri 1 Surabaya with a value of $F=77.993$ with a significant $(0.00)<(0.05)$. Susanto's research results (2012) show teacher competency, madrasa head leadership, and teacher work motivation on vocational teacher performance in Hulu Sungai Selatan Regency, South Kalimantan, both individually and jointly, and directly or indirectly.

The third finding shows that there is a positive and significant relationship together with the supervision of Madrasah Head learning and work motivation towards teacher performance with a correlation value of 0.643 . This shows the category of the relationship between the supervision of Madrasah Head learning and work motivation with the performance of madrasah ibtidaiyah teachers in Padang Tualang sub-district in the moderate category.

Supervision given by the headmaster to the teacher certainly helps the teacher in developing his teaching abilities. In the supervision program the madrasa head will discuss with teachers about the various shortcomings and weaknesses of the teacher and jointly find a solution. The madrasa head should be able to be a good partner of the teacher to find solutions in terms of learning, for example finding methods, media and strategies that are appropriate in delivering a number of subject matter.

Sometimes, without being realized by the madrasa head, teachers really expect guidance from the madrasa head in practical matters in teaching, especially if the teacher concerned is a new teacher or a beginner. With the supervision program, the guidance will be scheduled and structured to be carried out by the headmaster so that each teacher has the same opportunity to submit complaints and discuss with the headmaster. These things will encourage the teacher to continue working and show good performance in carrying out their duties.

If the supervision services provided by the madrasa head are very satisfying to the teacher, then the teacher will not have any complaints in carrying out the teaching. When this condition is supported by high work motivation, it will certainly cause teachers to feel that they have a madrasa as a place to fulfill their needs. There is no longer any desire to leave the madrasa. This will encourage improvement in teacher performance in carrying out their duties.

The teacher's response to the supervision carried out by the madrasa head is an assessment given by the teacher to the madrasa head on his treatment. The treatment of the madrasah head in supervision has a positive impact on the teacher concerned but also can have a negative impact. The ways and approaches to the supervision of the teacher will affect the job satisfaction of teachers.

Supervision given by the headmaster in improving the quality of teaching appropriately can increase the job satisfaction of the teacher concerned in carrying out their daily duties. Thus teacher job satisfaction is one measure of success in work that can be seen in the dimensions of discipline, quality, quantity of teacher attitudes. Job satisfaction is shown by its sense of responsibility to the burden of professionalism it carries. Indications that job satisfaction will increase if the teacher's response to the supervision of the headmaster is also high. 
The performance of Madrasah Ibtidaiyah teachers in Padang Tualang sub-district will also increase if the teacher's work motivation increases. This can be seen that teachers who have high motivation in terms of responsibilities, rewards, challenging work and so on, will be done with a full sense of responsibility and pleasure, so that conducive communication with all components of madrasas, especially madrasah teachers Ibtidaiyah, Padang sub-district of Padang Wanderer.

\section{Conclusion}

The conclusions of the study are: (1) there is a positive and significant relationship between the supervision of Madrasah Head learning and teacher performance. This means that the higher and more positive the supervision of learning provided by the madrasa head, the higher and more positive the teacher's performance by making an effective contribution of $27.36 \%$. This means that the variation that occurs in the variable giving supervision of Madrasah Head learning by $27.36 \%$ can be predicted in improving teacher performance, (2) there is a positive and significant relationship between work motivation and teacher performance. This means that the higher and more positive the work motivation, the higher and more positive the teacher's performance by making an effective contribution of $44.40 \%$. This can be interpreted that the variations that occur in the work motivation variable of $44.40 \%$ can be predicted in improving teacher performance, and (3) there is a positive and significant relationship together between providing supervision of Madrasah Head learning and work motivation with teacher performance. This means that the higher and more positive the supervision of madrasah head learning and teacher performance, the higher and more positive teacher performance by making an effective contribution of $41.30 \%$. This means that $41.30 \%$ of the variations that occur teacher performance can be predicted by the two independent variables. In other words, providing supervision of madrasah head learning and work motivation together can improve teacher performance with a linearity line $\hat{Y}=95.92+0.363 \mathrm{X} 1+0.515 \mathrm{X} 2$.

\section{References}

Anoraga, P. (2006). Psikologi Kerja. Jakarta: Rineka Cipta.

Ardiana, T., A. (2017). Pengarub Motivasi Kerja Guru Terbadap Kinerja Guru Akuntansi SMK di Kota Madiun. Journal: Akuntansi dan Pajak VOL. 17, No. 02.

Arikunto, S. (2006). Dasar-dasar Supervisi. Jakarta: Rineka Cipta.

Bahri, S. (2011). Faktor Yang Mempengarubi Kinerja Guru SD di Dataran Tinggimoncong Gowa Sulawesi Selatan. Journal: Medtek, Volume 3, No. 2.

Basri, H. (2014). Kepemimpinan Kepala Sekolah. Bandung: Pustaka Setia.

Gibson, James L., Ivancevich, John M., and Donelly, James H. (1997) Organization Alihbahasa:

Djarkasih, Organisasi, Prilaku, Struktur, Proses. Jakarta: Erlangga.

Guterres, L., A and Supartha, W., G. (2016). Pengaruh Gaya Kepemimpinan Dan Motivasi Kerja Terhadap Kinerja Guru. Journal: Ekonomi dan Bisnis Universitas Udayana 5.3.

Hariandja, M., T., E. (2005). Manajemen Sumber Daya Manusia. Jakarta: Grafindo.

Hasibuan, M. S. (2001).Organisasi \& Motivasi, Dasar Peningkatan Produktivitas. Jakarta: Bumi Aksara.

Ismail, T. (2017) Kepemimpinan, Kompensasi, Motivasi Kerja Dan Kinerja Guru SD Negeri. Journal: Administrasi Pendidikan Vol.XXIV No.1 April 2017.

Lumbanraja, Basaria., Absah, Yeni. Prihatin Lumbanraja. (2014). Pengaruh Gaya Kepemimpinan Dan Motivasi Kerja Terbadap Kinerja Guru Di SMP Negeri 1 Pandan, Journal: Bisnis dan Manajemen Eksekutif Vol. 1 No. 1.

Mishan. (2014). Pengaruh Motivasi Kerja Guru Dan Budaya Organisasi Terbadap Kinerja Guru SMA Negeri Di Kota Sibolga. Journal of Bisnis dan Manajemen Eksekutif Vol. 1 No. 2, 2014.

Moeheriono. (2009). Pengukuran Kinerja Berbasis Kompetensi. Bogor: Ghalia Indonesia. 
Mulyasa, E. (2005). Menjadi Kepala Sekolah Profesional. Bandung: Remaja Rosdakarya. . (2012). Manajemen dan Kepemimpinan Kepala Sekolah. Jakarta: Bumi Aksara.

Muslihah, E. (2014). Konstribusi Supervisi Kepala Sekolah Model Pengembangan Terbadap Profesionalisme Guru Sekolah Menengah Atas Negeri Provinsi Banten. Journal: Pendidikan dan Kebudayaan, Vol. 20, No. 3, September 2014.

Nawawi, H. (2006). Evaluasi dan Manajemen Kinerja di Lingkungan Perusabaan dan Industri. Yogyakarta: Gajah Mada University Pers.

Priansa, D.J., and Somad, R. (2014). Manajemen Supervisi \& Kepemimpinan Kepala Sekolah. Bandung: Alfabeta.

Pujiyanti and Isroah. (2015). Pengarub Motivasi Kerja Dan Disiplin Kerja Terhadap Kinerja Guru SMA Negeri 1 Ciamis. Journal: Kajian Pendidikan Akuntansi Indonesia.

Purwanto, M., N. (2005). Administrasi Dan Supervisi Pendidikan. Bandung: Remaja Rosdakarya.

Rugaiyah and Sismiati, A. (2011). Profesi Kependidikan. Bogor: Ghalia Indonesia.

Rivai, V., at el. (2005). Performance Aprraisal. Edisi Kedua: Raja Grafindo Persada.

Sagala, S. (2012). Konsep dan Makna Pembelajaran. Bandung: Alfabeta.

. (2007) Manajemen Strategik Dalam Peningkatan Mutu Pendidikan. Bandung: Alfabeta. - (2006). Administrasi Pendidikan Kontemporer. Bandung: Alfabeta.

Sahertian, Piet A. (2000). Konsep Dasar dan Teknik Supervisi Pendidikan Dalam Rangka Pengembangan Sumber Daya Manusia. Jakarta; Rineka Cipta.

Samsuadi. (2015). Pengaruh Supervisi Akademik dan Kepemimpinan Kepala Sekolah Terhadap Disiplin Kerja Guru. Journal: Journal of EST, Volume 1, No. 2, September 2015.

Septiana, Roslena, Ngadiman, Ivada, Elvia. (2013). Pengarub Kepemimpinan Kepala Sekolab dan Motivasi Kerja Terbadap Kinerja Guru SMP Negeri Wonosari. Journal: Jupe UNS, Vol 2 No 1, 2013.

Srinalia. (2015). Faktor-Faktor Penyebab Rendahnya Kinerja Guru Dan Korelasinya Terbadap Pembinaan Siswa. Journal: Didaktika VOL. 15, NO.2 February 2015.

Sudin, A. (2008). Implementasi Supervisi Akademik Terhadap Proses Pembelajaran Di Sekolah Dasar SeKabupaten Sumedang. Journal: Pendidikan Dasar “ Nomor: 9 April 2008

Susanto, H. (2012). Faktor-Faktor Yang Mempengarubi Kinerja Gutu Sekolag Menengah Kejuruan. Journal: Pendidikan Vokasi, Vol 2, No. 2, June 2012.

Syukri, Harun, Cut Zahri, and Usman, Nasir. (2015). Pelaksanaan Supervisi Akademik Oleh Kepala Sekolah Untuk. Meningkatkan Kinerja Guru Sekolah Dasar Pada Gugus I UPTD Dewantara Aceh Utara. Journal: Administrasi Pendidikan Pascasarjana Universitas Syiah Kuala, Volume 3, No. 2, May 2015.

Undang-Undang Nomor 14 Tahun 2005 tentang Guru dan Dosen

Uno, Hamzah B. (2017). Teori Motivasi Dan Pengukurannya. Jakarta: Bumi Aksara.

Wahidah, Siti. (2015). Pelaksanaan Supervisi Pengajaran Oleh Kepala Dalam Meningkatkan Kinerja Guru Di SMK Negeri 1 Banda Aceh. Journal: Magister Administrasi Pendidikan Universitas Syiah Kuala Volume 3, No. 3, August 2015

Wahjosumidjo. (2001). Kepemimpinan Kepala Sekolah. Tinjanan Teoretik Dan Permasalabannya. Jakarta: Rajagrafindo Persada.

Wahyudi, I. (2012). Pengembangan Pendidikan. Strategi Inovatif \& Kreatif Dalam Mengelola Pendidikan Secara Komprehensif. Jakarta: Prestasi Pustaka Publisher.

Wibowo. (2007). Manajemen Kinerja. Jakarta: Raja Grafindo Persada.

Yustiyawan, Rachman Halim and Nurhikmahyanti, Desi. (2014). Pengarub Motuvasi Dan Kompetensi Profesional Guru Yang Bersertifikasi Terhadap Kinerja Guru Di SMP Negeri 1 Surabaya. Journal: Inspirasi Manajemen Pendidikan, Vol. s3. No. 3, January 2014.

Zulkifli, Mohammad, Darmawan, Arif., and Sutrisno, Edy. (2014). Motivasi Kerja, Sertifikasi, Kesejabteraan Dan Kinerja Guru. Journal: Persona Jurnal Psikologi Indonesia, Vol. 3, No. 02 May 2014. 